\title{
Determinants of Green Consumer Behavior of Post graduate Teachers
}

\author{
RanjitKumar Siringi \\ Faculty Member, Department of Management Studies Andhra University Campus, Kakinada, India
}

\section{Introduction}

"Green" gains global marketing muscle, as consumers exercise the power of demand in the environmental arena. In light of public concern about climate change, depletion of natural resources, damage to the ozone layer, and loss of agricultural land, there is a growing preference for energy-saving technologies and a reduction and limit to energy use. Consumers will increasingly favour products and services from companies with strong sustainability practices .A major consequence of China's and India's rapid growth will be amongoing depletion of natural resources. Aspiration for economic progress and better life style will cause shortage in vital commodities (czinkota and scuba 2009)

Over the years, a majority of consumers have realized that their behaviour had a direct impact on environment. There is a growing amount evidence indicating that consumers are choosing products or avoiding others based on their impact on the natural environment (Laroche et al.,2001).As result of the increasing number of green consumers, marketers are targeting the green segment of the population. Recycled paper, plastic goods, and dolphin-safe tuna are examples of product positioned on the basis of environmental appeal(Banerjee et al.,1995).Marketers are also incorporating the environmental aspect into many marketing activities, including product and package design(Polonsky et.al.,1997) and pricing. It is also suggested that green consumers are wiling to pay more for ecologically friendly products(Coddington,1993).Marketers have even gone as far as to develop specific models for development of green advertising and green marketing strategies. Now days ,environmental consciousness is not only an ideology of activisits,but also a matter of "market competition", which influences consumer behaviour.D'souza(2004) claims that the green vision is a reality and needs to be more functionally understood to allow marketers to develop strategies aimed to meet green consumers, needs.

A number of contries have developed schemes in which a product that conforms to a set of criteria is granted a recognized seal of approval, better known as an eco-label. In India,the union ministry of environment and forests(MoEF)had introduced a scheme to label certain consumer products as environment-friendly products in 1991.Under the scheme, the products that are less harmful to the environment and human health or have begin impact on the environment through various stages of development, manufacture, use, packaging, distribution, consumption, disposal and re-cycleing may be awarded the Eco-mark label. The scheme is executed with the help of the Central Pollution Control Board(CPCB) and the Bureau of Indian Standards(BIS).The logo is that of the earthen pot,a symbol interwoven in the Indian way of life . But as of today, not a single product carries this mark.Godrej soaps was awarded the mark of their brand Eezee but the company has subsequently allowed its license to lapse(suneja 2010).

\section{Green Consumer Behaviour}

The tern "green "is typically used interchangeably with "pro-environmental" or "eco-friendly". However, because of difference in definitions of the environment, the term is necessarily imprecise. The term "green is simply used to indicate concern with the physical environment(air,water,land).Some authors have made finer distinctions in classifying different types of greenness (Iyer al.,1994).The term consumer behaviour is defined as the behaviour that consumers display in searching for,purchasing,using, evaluating and disposing of products and services that they will satisfy their needs(Sciffman\&Kanuk 2007).Hence, for this study the green consumer is considered as anyone whose behaviour is influenced by environmental concerns and the environmental concern that consumers display in searching for , purchasing,using,evaluating, and disposing of products is considered as 'Green Consumer Behaviour'.

\section{Review of literature}

Chamorro et al.(2009) built up a database with a hundred and twelve articles on green marketing and explored the topic: the methodology, techniques of analysis, and other relevant aspects of the research. The analysis revealed that research on green marketing has gone through two clearly distinct stages in the ten year period under analyses i.e.,1993-2003.It reached its peak during the 1990s, with an average of thirteen articles per year and the publication of various specific volumes dedicated to the topic, such as volume 20 of Advances in Consumer Research (1993) ,Volume 24/2 of Journal of Advertising(1995) and volume 14/6 of Journal of 
Marketing Management (1998).However, this initial interest appears to drop off after the year 2000,with a drastic and significant decline in the number of articles published. This fact can be related to the growing importance of "social corporate responsibility" that included both social and ecological dimensions as a general subject of research than ecological dimensions alone. Sanjay(2006) observed the presence of statistically significant linkages between the socio-demographic characteristics and different environmental consciousness constructs, thus implying potential usefulness of these characteristics in profiling different segments of green consumers and evolving accordingly the green marketing strategies and environmental campaigns as capable of more effectively reaching and influencing the chosen green consumer segments.

Level of education is an important demographic variable that has been linked to environmental attitudes and behaviour(e.g. Aaker and Bagozzi,1982;Anderson et al.,1974;LeonardBarton,1981;McEvoy,1972;Murphy et al.,1978;Roberts,1995;Roper,1990; 1992;Schwartz Miller,1991;Tognacci et al.,1972; Van Liere Dunlap,1981;Zimmer et al.,1994 Diamantopoulos et al.,2003) . The hypothesized relationship has been fairly consistent across these studies. Specifically, the results of studies examining education and environmental issues are somewhat more consistent than the other demographic variables, a definitive Roberts,1999). Samdahl (1989) found the opposite, that education was negatively correlated with environmental attitudes, and Kinnear et al.(1974) found no significant relationship.

Although education plays an important role in the encouraging change, this approach is often minimally successful. Education and sustained behaviour change in adults have a Zero percent correlation. Urban respondents scored high in all demographic categories in comparison with rural consumers. Gender-wise, the behaviour was quite symmertrical in both the groups. Education-wise, inverse relationship is noticeable between the Socially Responsible consumer Behaviour -mean values and education-level( Narendra Singh,2009). More than half of all consumers actively consider environmental sustainability characteristics in their buying decisions, but they go on to buy green products on fewer than a quarter of shopping occasions, according to new research( News \& Analysis Asia 2009).

As the literature reveals conflicting conclusion about the relationship of green consumer behaviour to education, the present study is conducted to understand the green consumer behaviour of university teachers, one of the highly educated segment The purpose of the current study is to investigate the relationship between education and in consumption to determine if a new green consumption mentality is emerging. Among the university teachers the study should be of interest and have practical value to both national and global marketers since knowledge of emerging consumer attitude guides in developing marketing campaigns designed around products that have appeal to local consumers. Additionally ,Since consumer environmental attitudes appear more fluid than stable, descriptive information on the current state of consumer environment orientation might assist in the development of more robust theoretical models explaining the presence of green consumer behaviour.

From a public policy standpoint, it is important to know what motivates consumers to buy environmentally friendly products if a pro-environmental change policy is to be successfully implemented . This study seeks to extend knowledge about green consumer behaviour of university teachers, where virtually no research has been conducted in the realm of eco-orientation.

\section{Objectives of the study}

This study is conducted with the following objectives:

1. To understand the green consumer behaviour of highly educated consumer segment,

2. To identify the factors that influences their green behaviour,

3. To examine whether Humanities and science faculty differ in green consumer behaviour, and

4. To distinguish between the teachers willing to purchase green products from teachers not willing to purchase in terms of predicator variables.

The null hypothesis is stated as:

$\mathrm{Ho}=$ There is no difference between teachers willing to buy and not willing to buy green products as measured by the relevant set of environmental concern variables

\section{Research methodology}

This descriptive study is conducted to know the green consumer behaviour of post graduate teachers. The respondents are selected from the Colleges of Arts and Commerce, science and technology and pharmaceutical sciences, Andhra University, Visakhapatnam, Andhara Pradesh, India. Self-selection sampling method(non-probability sampling)(Saunders et.al.2003) is used .A few Questions adopted in previous studies (e.g.,Straughan and Roberts 1999) were also included but most questions were specially developed for the study. After pilot study consisting of 30 respondents, the final version of the questionnaire was formulated. It consisted of 2 sections. The first section was of demographic data such as age, sex, monthly family income and 
family size. The education and occupation being common, no questions on these details were included. The second section consist of purchase behaviour items .

The teacher served with the questionnaire were 213 of Science faculty and 162 of Humanities faculty. Out of the total 375 served, a total of 160 teachers responded by the cut-off date,i.e., $43 \%$ of the total population. Around a third of the participants (31 percent) were females. All the variables used in this study were measured on five point Likert-scale(1:strongly disagree; 5: strongly agree). The scale is reversed for negative statements.

\subsection{Statistical Analysis}

SPSS software is used for analysis of the data. Simple percentages are used for analysis of demographic data, environmental information sources, awareness of eco-friendly product disposal activity. Rank correlation is used measure the correlation that exist between the ranks of faculties of humanities and sciences to purchasing criteria factors analysis is used to determine the factors underlying green consumer behaviour of the post graduate teachers. Stepwise Discriminant Analysis is applied to establish a relationship between the independent variables (factors), in terms of their relative importance, and dependent variable (the willingness of the teachers to purchase green products).

\section{Results of Data Analysis}

\subsection{Characteristics of the Respondents}

The profile of the respondents shows that a majority of them are males belonging to the age group of 52 to 60 years and having a monthly family income between and Rs.1,00,000.Most of them have three members in the family. As the respondents are all university teachers, their education level is Ph.D. The sample is almost evenly distributed between sciences and humanities faculty groups.Demographic Profile of 160 respondents used in the study is provided in Table1.

Table1 Demographic Characteristics of Respondents

\begin{tabular}{|c|c|c|}
\hline Characteristics & No. Of respondents & Percentage \\
\hline \multicolumn{3}{|c|}{ Age } \\
\hline$<30$ Years & 3 & 1.9 \\
\hline $30-40$ Years & 14 & 8.8 \\
\hline 40-50 Years & 39 & 24.4 \\
\hline $50-60 \quad$ Years & 91 & 56.9 \\
\hline$>60$ Years & 13 & 8.1 \\
\hline \multicolumn{3}{|c|}{ Gender } \\
\hline Male & 111 & 69.4 \\
\hline Female & 49 & 30.6 \\
\hline \multicolumn{3}{|c|}{ Family size } \\
\hline 1 & 13 & 8.1 \\
\hline 2 & 28 & 17.5 \\
\hline 3 & 99 & 61.9 \\
\hline 4 & 16 & 10.0 \\
\hline 5 & 4 & 2.5 \\
\hline \multicolumn{3}{|c|}{ Family Monthly Income (Rs.) } \\
\hline$<$ Rs. $50,000 /-$ & 24 & 15.0 \\
\hline Rs.50,001-Rs.75,000/- & 27 & 16.9 \\
\hline Rs.75,001-Rs. $1,00,000$ & 61 & 38.1 \\
\hline Rs.1,00,000-Rs. $1,50,000$ & 1 & .6 \\
\hline Rs.1,50,000- Rs.2,00,000 & 14 & 8.8 \\
\hline$>$ Rs. $2,00,000$ & 9 & 5.6 \\
\hline \multicolumn{3}{|c|}{ Faculty of the respondent } \\
\hline Sciences & 79 & 49.4 \\
\hline Humanities & 81 & 50.6 \\
\hline
\end{tabular}

\subsection{Sources of Environmental Information}

Information from the consumer point of view may be considered as knowledge obtained for use in a consumer-behaviour situation. Information search may be undertaken by the consumers to find out about products, prices, stores, and so on, related to the product. They use internal and external sources to satisfy their information need. A greater diversification of information sources may typically provide for better knowledge 
evolution. When respondent (33\%) are using both internal and external sources followed by $25 \%$ using print magazines and TV. University teachers consider Magazines and TV as important sources of environmental information products. Marketers should communicate through this media and satisfy their information need. This external source strengthen their internal source this data is presented in Table 2.

Table2 Sources of Environmental Information

\begin{tabular}{|l|l|l|}
\hline Source & Frequency & Percent \\
\hline Past experience & 15 & 9.4 \\
\hline Friends and relatives & 19 & 11.9 \\
\hline Websites & 6 & 3.8 \\
\hline Consumer groups & 4 & 2.5 \\
\hline Magazines and TV & 40 & 25.0 \\
\hline Govt Agencies & 9 & 5.6 \\
\hline Advertisements & 10 & 6.3 \\
\hline Product trial interested in & 1 & 0.6 \\
\hline Sales personnel & 1 & 0.6 \\
\hline All of the above & 53 & 33.1 \\
\hline $\begin{array}{l}\text { Not } \\
\text { Environmental Information }\end{array}$ & 160 & 1.3 \\
\hline Total & & 100.0 \\
\hline
\end{tabular}

\subsection{Awareness of Green Product:}

Consumer's awareness plays an important role in purchasing behaviour. To know the awareness of green products among the responders, they were asked to select from a list of some common green consumer products. Their responses are presented in table 3. Majority of respondents ( $82.5 \%$ ) are aware of all the products followed by the awareness of paper/ cotton/ jute bags and solar powered products. They use the external and internal information sources to become aware of green products.

Table 3 Awareness of green products

\begin{tabular}{|l|r|r|}
\hline Product & Frequency & Percent \\
\hline Recycled paper/hand made paper & 1 & 0.6 \\
\hline Paper/jute/cotton fabric bags & 9 & 5.6 \\
\hline Fluorescent lamps & 2 & 1.3 \\
\hline Solar powered products & 7 & 4.4 \\
\hline Cars and other motor vehicles & 5 & 3.1 \\
\hline Solar heating & 3 & 1.9 \\
\hline Natural soaps and detergents & 1 & 0.6 \\
\hline All of the above & 132 & 82.5 \\
\hline Total & 160 & 100.0 \\
\hline
\end{tabular}

\subsection{Purchase Decision}

It is not uncommon to enter a retail outlet with the intention of purchasing a particular brand but leave with a different brand or additional items. Influence of various factors induce additional information and subsequently affect the final purchase decision. The decision criteria, the consumers use to evaluate and by a brand of a product is used by the marketers for segmentation. Respondents are asked to rank their decision criteria to understand the importance of environmental concern in their purchasing decision. Quality has received top rank followed by price. Science faculty ranked environment friendliness as fourth important decision criterion but humanities faculty ranked it fifth. The ranks given to various factors by the respondents are presented in Table 4.

Table 4 Ranks of purchasing Criteria

\begin{tabular}{|l|l|l|l|l|l|l|l|l|l|l|}
\hline $\begin{array}{l}\text { Faculty/ } \\
\text { Criterion }\end{array}$ & Price & Q & A & B & C & EF & URM & MRE & PR & EE \\
\hline Humanities & 2 & 1 & 8 & 4 & 3 & 5 & 10 & 7 & 9 & 6 \\
\hline Science & 2 & 1 & 10 & 3 & 5 & 4 & 9 & 7 & 8 & 6 \\
\hline
\end{tabular}

$\mathrm{Q}=$ Quality, A=Advertising, $\mathrm{B}=$ brand, $\mathrm{C}=$ Certification, EF=Environmental Friendly, URM=Used Recycled material, MRE=Manufacturers reputation for Environment, $\mathrm{PR}=$ product recyclables, EE=energy efficient. 
Rank correlation coefficient is used to measure the correlation between the ranks given to purchase criteria by the faculties of humanities and sciences. A correlation coefficient of 0.927 suggests a highly positive association between the ranks of humanities and sciences and significant at 0.01 level

Table 5 Rank Correlation

Correlations

\begin{tabular}{|c|c|c|c|c|}
\hline & & & Humanities & Sciences \\
\hline Spearman's rho & Humanities & $\begin{array}{l}\text { Correlation } \\
\text { Coefficient } \\
\end{array}$ & 1.000 & $.927 * *$ \\
\hline & & Sig.(2-tailed) & $\cdot$ & .000 \\
\hline & & $\mathrm{N}$ & 10 & 10 \\
\hline & Sciences & $\begin{array}{l}\text { Correlation } \\
\text { Coefficient } \\
\end{array}$ & $.927 * *$ & 1.000 \\
\hline & & Sig.(2-tailed) & .000 & . \\
\hline & & $\mathrm{N}$ & 10 & 10 \\
\hline
\end{tabular}

**Correlation is significant at the 0.01 level (2-tailed)

In purchase decision criteria, the respondents ranked Quality as prime factor and price is ranked second.. Environmental concern received fifth and fourth ranks by Humanities and sciences respectively. But $67.5 \%$ said they buy green products and $34 \%$ of the respondents buy lowest priced product irrespective of its impact on environment. This shows that there is a visible difference between their environmental concern and behaviour.

\subsection{Product Disposal}

Attitudes and behaviour of consumers towards the environment has become a major global concern over the last few decades. While everyone is aggressive, particularly in a country like India, in the age of communications and goods with advanced electronics systems- with the cell phone, PC's refrigerators and the like- little thought has been given to the disposal of these goods after use. One buy a new cell Phone or PC and hands down the old one or simply dump it somewhere. It may be out of sight, but it certainly isn't out of mind, so far as the environment is concerned. In order to know the product disposable behaviour the respondents were asked to select their disposing activities relating to consumer durables and electronic products. All the activities mentioned are used by $40.6 \%$ of respondents, because the disposing activity varies for different types of products. Only two percent said they through it in the garbage. This shows that they have concern for environment when they dispose of the products. More visible and clear recycling directions on product packing and through advertisement provide green disposable solutions. This information is providing in Table 5:

Table 5 Product Disposal Behaviour

\begin{tabular}{|l|c|c|}
\hline Disposal Activity & Frequency & Percent \\
\hline $\begin{array}{l}\text { See it will not cause any damage to the } \\
\text { environment }\end{array}$ & 17 & 10.6 \\
\hline Follow the disposal instructions on the package & 22 & 13.8 \\
\hline Reuse the packing material & 5 & 3.1 \\
\hline Reuse the product after repair & 20 & 12.5 \\
\hline Sell the product in the secondary market & 16 & 10.0 \\
\hline Exchange the product for a new product & 8 & 5.0 \\
\hline Donate to charity & 4 & 2.5 \\
\hline Through it in the garbage & 3 & 1.9 \\
\hline All of the above & 65 & 40.6 \\
\hline Total & 160 & 100.0 \\
\hline
\end{tabular}

Independent samples T-test (SPSS) is used to know whether the green consumer behaviour of science faculty differs with that of humanities faculty. As there is no significant difference between the two means, it is concluded that the two groups are associated with the same green consumer behaviour.

\subsection{Results of Factor Analysis}

The Kaiser- Meyer-Olkin measure of sampling Adequacy was 0.698 while the Barlett's Test of Sphericity was significant at 0.000 . Both tests indicate that factor analysis was appropriate for use with this data set ( Noursis, 1990). The results of the principal components factor analysis using a varimax rotation yielded eight factors with eigen values higher than 1.00 that explain $64.32 \%$ of the variance. The first three factors together explain as much as $33.4 \%$ of variance. Table 6 presents the summary of factor analysis. 
The first factor explained $13.3 \%$ of the variance and was named " Energy Saving”. Individuals included in this factor purchase energy efficient and recyclable products and consider that each consumer's behaviour effects environment. The factors loadings ranged from 0.795 to 0.531 .

The second factor explained $10.54 \%$ of the variance and was labeled "Eco-label". This factor was composed of five activities including " I purchase the green products if they are certified by environmental organization', 'I trust the eco- friendly claims in the advertisements', marketers must advertise the environmental information and making eco- labelling mandatory. They prefer to purchase products in reusable containers. Factor loadings ranged from 0.652 to 0.523 .

The third factor explained $9.56 \%$ of the variance and was labeled " Need for environmental information". Individuals agreeing with these statements are too busy to change and would most likely need environmental information to change to green purchasing behaviour. Factor loadings ranged from 0.741 to 0.632 .

The fourth factor explains $6.57 \%$ of the variance was labeled " Shopping Behaviour". The statements measure consumer's attitude toward 'Changing the consumer durables (Ex. TV, Refrigerator, Computer etc) frequently causes damage to the environment' and ' I use shopping bag to avoid plastic carry bags'. Factor loadings were 0.779 and 0.511 . The fifth factor explained $6.56 \%$ of the variance and was labeled "Purchase criteria", These statements appear to measure the 'Plastic carry bags are more convenient and should not be banned' and 'I usually purchase the lowest priced product, regardless of its impact on society'. Factor loadings were 0.730 and 0.700 .

The sixth factor explained $6.21 \%$ of the variance. This factor was labeled "purchasing behaviour". The statements relates to' Do you or another member of your family buy green products if available? 'Factor loading was 0.818 .

The seventh factor explained $5.86 \%$ of the variance and was labeled "preference of green outlet". This one item factor relates to separate shops to sell environment friendly products. The factor loading was 0.873 .

The eight factors explained $5.7 \%$ of variance and were labeled "Awareness of green outlets". This one item factor relates to awareness of any exclusive shops for environment-friendly products. The factor loading was 0.875 .

Table-6 Factors Influencing green Consumer behaviour

\begin{tabular}{|c|c|c|c|c|}
\hline $\begin{array}{c}\text { Fact } \\
\text { or }\end{array}$ & $\begin{array}{l}\text { Factor } \\
\text { Interpretation }\end{array}$ & $\begin{array}{l}\text { \%variance } \\
\text { explained }\end{array}$ & Loading & Variables included in the factor \\
\hline \multirow[t]{5}{*}{ F1 } & $\begin{array}{l}\text { Energy } \\
\text { Saving }\end{array}$ & 13.3 & .795 & I try to buy energy efficient household appliances \\
\hline & & & 690 & I try to buy products that can be recycled \\
\hline & & & .676 & $\begin{array}{l}\text { Each consumer's behaviour can impact on } \\
\text { environment }\end{array}$ \\
\hline & & & .653 & $\begin{array}{l}\text { To save energy, I drive my vehicle as little as } \\
\text { possible }\end{array}$ \\
\hline & & & .531 & I have switched products for ecological reasons. \\
\hline \multirow[t]{5}{*}{$\mathrm{F} 2$} & Eco-label & 10.54 & .652 & $\begin{array}{l}\text { Whenever possible, I buy products packaged in } \\
\text { reusable containers }\end{array}$ \\
\hline & & & .638 & $\begin{array}{l}\text { I purchase the green products if they are certify } \\
\text { by environmental organization }\end{array}$ \\
\hline & & & .631 & $\begin{array}{l}\text { I trust the Eco-friendly claims in the } \\
\text { advertisement }\end{array}$ \\
\hline & & & .562 & $\begin{array}{l}\text { Marketers must advertise the environmental } \\
\text { aspects of their products }\end{array}$ \\
\hline & & & .523 & Government must make eco-labeling mandatory. \\
\hline \multirow[t]{4}{*}{ F3 } & $\begin{array}{l}\text { Need for } \\
\text { environmental } \\
\text { information }\end{array}$ & 9.56 & .741 & $\begin{array}{l}\text { I have doubt about the true impact of green } \\
\text { products }\end{array}$ \\
\hline & & & .666 & $\begin{array}{l}\text { I am not sure which products and packing } \\
\text { material are recyclable. }\end{array}$ \\
\hline & & & 656 & $\begin{array}{l}\text { Do not have the information to be personally } \\
\text { involved in green behaviour. }\end{array}$ \\
\hline & & & 632 & $\begin{array}{l}\text { I know that I should change to green life style but } \\
\text { too busy }\end{array}$ \\
\hline F4 & $\begin{array}{l}\text { Shopping } \\
\text { Behaviour }\end{array}$ & 6.57 & .779 & $\begin{array}{l}\text { Changing the consumer durables ( Ex. TV, } \\
\text { Refrigerator, Computers etc) frequently causes }\end{array}$ \\
\hline
\end{tabular}




\begin{tabular}{|l|l|l|l|l|}
\hline & & & & damage to the environment. \\
\hline F5 & Purchase Criteria & 6.56 & .730 & $\begin{array}{l}\text { Ilastic carry bags are more convenient and should } \\
\text { not be banned }\end{array}$ \\
\hline F6 & $\begin{array}{l}\text { Purchasing } \\
\text { Behaviour }\end{array}$ & 6.21 & .818 & $\begin{array}{l}\text { I usually purchase the lowest priced product, } \\
\text { regardless of its impact on society }\end{array}$ \\
\hline F7 & $\begin{array}{l}\text { Preference of } \\
\text { green outlet } \\
\text { green products if available? }\end{array}$ \\
\hline F8 & $\begin{array}{l}\text { Awareness of } \\
\text { green outlets }\end{array}$ & 5.86 & .873 & $\begin{array}{l}\text { There must be separate shops to sell environment } \\
\text { friendly products }\end{array}$ \\
\hline
\end{tabular}

\section{References:}

[1] Burroughs and Sabherwal, "Online Shopping Behaviour", "AIMS Volume 3 , Number2, May2009

[2] Catledge and Pitkow, "Characterizing Browsing Strategies in the World Wide Web Computer Networks and ISDN Systems, 27(6), 1065-1073.

[3] Chen, 'Gender and Computers: The beneficial effects of experience on attitudes'. Journal of Educational Computing Research, 2, 265-282.

[4] Christ et al, "Trajectories of Individual WWW Usage: Implications for Electronic Commerce. In Proceedings of the $34^{\text {th }}$ Hawaii International Conference on System Sciences, Maui, HI, January 3-6, 2001 (pp.2794-2802) los Alamitors: IEEE Computer Society.

[5] Chung et al, "Internet Searching and Browsing in a Multilingual World: An Experiment on the Chinese Business Intelligence Portal (CBizPort). Journal of the American Society for Information Science and Technology, 55(9), 818-831.

[6] Cockburn and McKenzie, "What do Web users do: An Empirical Analysis of Web Use" International Journal of Human-Computer Studies, 54(6), 903-922.

[7] Cumming," Hits and Miss -es: A year Watching the Web, Computer Networks and ISDN Systems, 29(8-13), 1357-1365.

[8] Davies, D.W., K.A. Bartlett, R.A. Scantlebury, and P.T. Wilkinson. 1967. "A Digital Communication Network for Computers Giving Rapid Response at Remote Terminals", Proceedings of the ACM Symposium on Operating System Principles. Association for Computing Machinery, New York, 1967

[9] Davis, F.D. (1989). "Perceived Usefulness, Perceived Ease of Use, User Acceptance of Information Technology.” MIS Quarterly, $13,319-340$.

[10] 'Neslihan Keser Ozcan, ' Internet Use and Its Relation with the Psychosocial Situation for Sample of University Students', Cyber Psychology \& Behaviour, Volume 10, No.6, 2007

[11] S.L.Gupta, Online Shoping Behaviour, Aims International Journal Volume 3,Number2-May 2009, P.119.

[12] Raj Gupta, President, Insight, Aims International Journal Volume 3, Number2-May 2009, P.119

[13] Mathwick, Malhotra and Rigdon, (2009), "Online Shopping Behaviour", AIMS International Journal Vol.3, No.2, pp.134.

[14] Wokfin Bargeo and Gilly, (2009) "Online Shopping Behaviour” AIMS International Journal, Vol.3, No.2, pp.134.

[15] Yen-Hao, (2008) "Toward an understanding of the behavioral intention to use Online news services:An exploratory study" ,Internet Research: www.emeraldinsight.com/1066-2243.htm, Vol.18, No.3, pp.286

[16] Victor Perotti, (2005) “Attitude and age Differences in online buying” Rochester Institute of technology", International Journal of Retail \& Distribution Management, Vol.33, No.2, pp.142

[17] Jari salo and Heikki korjalnoto, (2007) "A Conceptual model of trust in the online environment", Online Information Review,Vol.31, No.5, pp.604

[18] Jihyun kim and Jihye park, (2005) "A consumer shopping channel extension model : Attitude shift toward the online store", Jou rnal of Fashion Marketing and Management, Vol.9, No.1, pp.106

[19] Delia Vazquez and Xingang Xu, (2009) "Investigating linkages between onlinePurchase behaviour variables", International Journal of Retail \& Distribution Management, Vol. 37, No.5, pp.408

[20] E. Gattiker Stefano Perlusz, (2000) "Using the Internet for B2B activities: a review and future directions for research", Internet Research: Electronic Networking Applications and policy,Vol.10, No.2, pp.126

[21] Stuart J. Barnes, (2007) "Segmenting cyber space: a customer typology for the Internet", European Journal of Marketing,Vol.41, No.2, pp.71

[22] Rebeca San Jose - Cabezudo, (2008) “ The moderating role of user motivation in Internet access and individuals' responses to a website”, Emerald Group Publishing Limited(1066-2243) Vol.18, No.4,pp.393

[23] Shirley Atkinson, (2007) “Theme Article Improving protection mechanisms byunderstanding online risk', Information Management \& Computer Security, Vol.15, No.5, pp382.

[24] Kennet C.C. Yang, (2005) "Consumers' attitudes toward regulation of Internet auction sites A third-person effect perspective" Emerald Group Publishing Limited(1066-2243), Vol.15, No.4, pp.359

[25] Zorotheas A and E. Kafeza, (2009) "Users' perceptions on privacy and their intention to transact online: a study on Greek Internet users", direct marketing : An International Journal, Vol.3, No.2, pp.139 